\title{
COMPARATIVE STUDIES BETWEEN SEAWEEDS AND COMMERCIAL ALGAE IN ALLEVIATION OF HARMFUL EFFECTS OF DROUGHT STRESS OF FABA BEAN (VICIA FABA L.) PLANTS
}

\author{
A. D. El-Gamal, M. A. Ismail, M. A. Amin and A. M. Sayed \\ Botany and Microbiology Department, Faculty of Science, Al-Azhar University, \\ Cairo, Egypt.
}

Received: May 18, 2020

Accepted:Jun.13, 2020

\begin{abstract}
The effect of seaweed extract (SWE) obtained from two macroalgae species (Sargassum latifolium and Corallina elongate) and two commercial algae (Canada power and oligo $x$ ) on drought stress tolerance in faba bean (Vicia faba L.) plants was studied. Examination of growth parameters and some physiological and biochemical parameters showed that SWE extract and commercial algae under stress conditions enhanced shoot length and decreased root length, in most cases, at stages $1 \& 2$ in faba bean plants with comparison to stress conditions. All treatments, mostly, caused decreases in fresh and dry weight of faba bean plants under drought stress. Maximal increases in shoot and root lengths were observed in stress case in presence sargassum extracts in comparison to drought stress. Number of leaves, flowers and yield parameters decreased in response to drought. Bio stimulant especially sargassum extract caused increasing in these parameters. In most cases, Chl.a, Chl.b, Chl. a+b and carotenoids of leaves of faba bean plants increased at stage 1 and decreased at stage 2 as a result of all treatments. Carbohydrate and protein contents of root, shoot and seed yield showed increases under stress of faba bean plants. Amylase and protease activities revealed different responses to all treatments. With respect to antioxidant enzymes, peroxidase activity of faba bean plants at both stages of growth increased in response to all treatments, with exceptions of stress + sargassum and stress + Canada power at stage1. In case of activities of super oxide dismutase and poly phenol oxidase showed decreases at both stages of growth with comparison to stress conditions, with exception of super oxide dismutase at stag 2 of faba bean plants. Total phenolic content was increased in faba bean plants under different treatments (with exception of treatment with stress + Canada power) with respect to stress conditions. Acidic growth hormones, IAA, GA3 and ABA exhibited increases in GA3 contents of faba bean plants as a result to all treatments as comparison to stress condition, however IAA and ABA contents decreased, with exception of treatment with stress + sargassum extract in case of ABA. The increased total phenolic content and the enhancement of antioxidant enzymatic activity by SWE and commercial algae in stressed faba bean plants may contribute to protection against peroxidation and reduce the severity of water deficit.
\end{abstract}

Key words: Seaweed extract, macroalgae, stress tolerance, antioxidant enzymes, carotenoids, bio stimulates

\section{INTRODUCTION}

The faba bean (Vicia faba), is known for its high protein concentration in its seeds. It ranks fourth among the most important legume crops in the world, after dry beans, dry peas and chickpeas.
The crop is a stable food that provides adequate nutrition to many people in the Middle East (Ammar et al., 2017). Legumes are a major source of protein in human and animal nutrition and play a key role in crop rotations in most parts of 
the world. When it grows in rotation with other crops, under certain environmental conditions, they can improve soil fertility and reduce the incidence of weeds, diseases and pests (Mwanamwenge et al., 1998).

Agriculture is facing the dual challenges of increasing crop production and climate change. Rising temperature, drought, salinity, floods, desertification and weather extreme are adversely affecting agriculture especially in developing world IPCC (2007). Environmental factors are essential components which effect on quality and quantity of crop yield to a great extent. The introduction of resistance to salt, cold, and drought into crop plants have become a topic of major economic interest for agriculture. In the case of drought, scientists have been able now to uncover some of the extremely intricate mechanisms through which seed from orthodox plants acquires tolerance to desiccation during their final maturation period (Oliver et al., 2010). Drought triggers a wide variety of plant responses (Ajum et al., 2011).

Global climate change makes drought a serious threat to food security worldwide. Drought, as an abiotic stress, is multidimensional in nature, and it affects plants at various levels of their organization. Three main mechanisms reduce crop yield by soil water deficit: (1) reduced canopy absorption of photosynthetically active radiation, (2) decreased radiation-use efficiency and (3) reduced harvest index (Earl and Davis, 2003). Therefore, use of foliar application of algae (algal extract and commercial algae) may have become a new trend to reduce the harmful effects of drought on some crops.

Drought stress has pronounced effects on the growth, phenology, water and nutrient relations, photosynthesis, assimilate partitioning, and respiration in the form of physiological, biochemical, and molecular responses (Usman, 2014).

Seaweeds are excellent source of vitamins A, B1, B12, C, D and A, riboflavin, niacin, pantothenic and folic acid. (Thirumaran et al., 2009) stated that recent researches proved that seaweed fertilizers are preferred not only due to their nitrogen, phosphorus and potash content but also because of the presence of trace elements and metabolite similar to plant growth regulators. Recently, seaweed extracts as liquid fertilizers has come in the market for the simple reason that they contain many growth promoting hormones like auxin, gibberellin, trace elements, vitamins, amino acids and micronutrients. (Strik et al., 2004) reported that the seaweeds extracts are effective fertilizers in many crops.

The using of seaweed products improve seeds germination, seedlings development, increase plant tolerance to environmental stresses (Zhang and Ervin, 2008), and enhance plant growth and yield (Kumari et al., 2011). Liquid extracts obtained from seaweeds have gained importance as foliar sprays and soil drench for many crops including various grasses, cereals, flowers and vegetable species. Also, they apply to stimulate seedling germination and rooting. At present one of the most promising applications of seaweeds is their use as plant bio stimulants. For example, aqueous extracts of Sargassum johnstonii at concentration from 0.1 to $0.8 \%(\mathrm{w} / \mathrm{v})$ that is equivalent $1-8 \mathrm{mg} \mathrm{SW}$ $\mathrm{mL}^{-1}$ used as foliar spray and soil drench enhanced vegetative growth (plant height, shoot length, root length, and number of branches) and reproductive parameters (flower number, fruit number, and fresh weight) of tomato (Kumari et al., 2011).

Seaweed extracts are often regarded as soft or natural products that can 
influence crop growth and development (Norrie and Hiltz, 1999). A wide range of beneficial effects has been observed including increasing crop yield, nutrient uptake, resistance to frost and stress conditions, longer shelf life of fruit, improved seed germination, and reduced incidence of fungal and insect attack and reduced the effect of salinity stress on membrane permeability (Wang et al., 2005). The effect of crude seaweed extracts of three green seaweeds (Cladophora dalmatica, Enteromorpha intestinalis, Ulva lactuca) and the three red algae (Corallina mediterranea, Janiarubens, Pterocladia pinnate) from the Egyptian Mediterranean Sea coast were studied by (El-Sheekh and El-Saied, 2000) on seed germination, growth of seedlings, chlorophyll content and other metabolic activities of Vicia faba, They found that the crude extract of $C$. dalmatica showed maximal activity, and it increased seed germination, length of main root and shoot systems and the number of lateral roots. Also, all the crude extracts of seaweed increased protein content in root and shoot systems, total soluble sugars and chlorophyll content in leaves. The cytokinin content of the green algae was higher than that in red algae. Growth of seedlings of Vicia faba was stimulated but to different degrees.

Canada power is commercial product contain Ascophyllum nodosum as main source of biofertilizer. Ascophyllum nodosum is a large brown alga (up to $2 \mathrm{~m}$ ) of the Fucaceae family which is common on both sides of North Atlantic Ocean (Martin et al., 2015). Oligo-X is commercial product contain oligosaccharides $3 \%$ and alginic acid $5 \%$. oligosaccharides are model compounds to represent domains from the larger, more complex polysaccharides (Kinnaert et al., 2017). Alginic acid obtained from brown algae; $61 \%$ mannuronic acid and $39 \%$ guluronic acid (Parker et al., 2015).

This study was conducted to investigate the influence of spray field application of seaweed extract (SWE) and commercial algae for mitigating harmful effects of drought stress on growth, yield and biochemical constituent of faba bean plants in order to select a suitable bio stimulant to this purpose.

\section{MATERIALS AND METHODS}

\section{Plant material:}

Seeds of faba bean (Vicia faba misr 1) plants were obtained from Agricultural Research Centre, Ministry of Agriculture, Giza, Egypt.

Methods of planting, treatments and collection of samples:

Sargassum latifolium (Turner) C. Agardii was collected from Hurgada Red Sea coast in June 2019 and Baltim, while Corallina elongate $\mathrm{J}$. Ellis was collected in May 2019 from shallow water beside the shore of Mediterranean Sea at AbouQuair coast in Egypt. Collecting algae were washed with fresh water then were dried in the oven at $60^{\circ} \mathrm{C}$ for 5 hours, hand crushed and powdered with coffee-grinder, then heated in sterile distilled water in a ratio 1: $100(\mathrm{w} / \mathrm{v})$ at 60 ${ }^{\circ} \mathrm{C}$ for $45 \mathrm{~min}$. The extracts were filtered through a filter paper and stored at $4{ }^{\circ} \mathrm{C}$ for further experimental studies. Concentrations of extracts were prepared by diluting these extracts with distilled water (Mikhail et al., 2013). The algal extracts and commercial algae (Canada power and Oligo-x) were applied as a foliar treatment at the rate of $4 \mathrm{~g}$ powdered algae/L and $4 \mathrm{ml} / \mathrm{L}$ of commercial algae, after 30 and 60 days from sowing. 
A. D. El-Gamal, et al.,

\section{Treatments and experimental design:}

Uniform faba bean seeds were planted in natural loamy soil conditions in a plot (12 $\mathrm{m}$ width and $15 \mathrm{~m}$ length) containing 6 groups representing the following treatments: control (tap water every 7 days), drought stress (tap water every 14 days), drought stress in presence Corallina extract, drought stress in presence Sargassum extract, drought stress in presence Canada power as commercial algae and drought stress in presence Oligo- $x$ as commercial algae The seeds were sown on one side of the ridge, with $10 \mathrm{~cm}$ apart between the hills. The in Botanical garden, Botany and Microbiology Dept., Fac. of Sci., Al- Azhar Univ., Nasr City, Cairo, Egypt, developed plants were irrigated whenever required. Concentrations of the used treatments were chosen according to a preliminary experiment in which they caused a maximum germination percentage. The plants were sprayed twice with the above-mentioned treatments, the first and second were added at 30 and 60 days of plant age respectively. The plant samples were collected for analysis when the plants were 37 (Stage I) and 67 (Stage II) days old. At the end of the growth season, analysis of the seeds yielded from the different treatments and the control were done.

\section{Determination of Metabolites content of Faba bean:}

Chlorophylls contents of were
estimated using the method of
(Vernon and Selly, $\begin{array}{r}1966) . \\ \text { were }\end{array}$
$\begin{aligned} & \text { Carotenoids contents of } \\ & \text { estimated according } r\end{aligned}$ to
(Lichtenthaler, 1987). $\begin{array}{r}\text { Soluble } \\ \text { carbohydrates were measured }\end{array}$
according to the method of (Umbriet
et al., 1969). Contents of soluble
proteins were estimated according to
the methods of (Lowery et al., 1951).

A phenolic compound (mg/100 g of dry wt) was carried out according to that method described by (Daniel and George, 1972). Activities of amylases were determined using the method of (Afifi et al., 1986). Proteases activities were estimated using the method of (Ong and Gaucher, 1972). Peroxidase activity was assayed using the method of (Jaworek, et al., 1974). Superoxide dismutase activity was. determined by measuring the inhibition of the auto-oxidation of pyrogallol using a method described by (Marklund and Marklund, 1974). The activity of polyphenoloxidase enzyme was determined according to the method adopted by (Matta and Dimond, 1963). The method of extraction of endogenous acidic phytohormones extraction was essentially similar to that adopted by (Shindy and Smith, 1975) and described by (Hashem, 2006).

\section{Statistical Analysis:}

Results were statistically analyzed by calculating the analysis of variance, in completely randomized design (Snedecor and Cochran, 1982).

\section{RESULTS AND DISCUSSION}

\section{Morphological responses and} yield parameters:

The present results in Table (1) revealed that algal extracts of (Sargassum latifolium and Corallina elongate) and two commercial algae (Canada power and oligo $\mathrm{x}$ ) under stress conditions enhanced shoot length and decreased root length, in most cases, at stages I and II in faba bean plants with comparison to stress treatment. Maximum enhancement increases in shoot lengths were observed in presence sargassum extracts. Our results agree with those of (Bassal and Zahran, 2002) 
revealed that the blue green algae addition significantly increased flag leaf area, plant height of rice (Oryza sativa) plants. The importance of SWE in stress water effect can be correlated to improvement of glycine betaine content in treated plants. In several plant species, a positive correlation between leaf osmotic potential and glycine betaine, $\beta$ alanine betaine, and proline betaine has been observed (Rhodes and Hanson, 1993). These organic compounds are now known to also have osmoprotective effects in the cell (Ashraf and Harris 2004). Seaweed concentrate prepared from Ecklonia maxima (Kelpak) was found to increase the root length and root number of Pinus pinea seedlings (Atzmon et al., 1994), increased root and shoot growth in three species of Eucalyptus (Van Staden et al.,1995) and promoted root formation in a variety of plants (Crouch and Van Staden, 1991), which has been attributed to the relatively high concentrations of indoles present in the extract (Crouch et al., 1992).

The obtained results in Tables $(2,3$ and 4) showed decreases in fresh, dry weight, No. of leaves, flowers and branches of faba bean plants in response to drought stresscompared to the control plants. All treatments caused improvement of this parameters with comparison to stress treatment. The increases in some of growth parameters coincides with results of (Kumari et al., 2011) showed thataqueous extracts of Sargassum johnstonii at concentration from 0.1 to $0.8 \%(w / v)$ that is equivalent 1-8 $\mathrm{mg} \mathrm{SW} \mathrm{mL}^{-1}$ used as foliar spray and soil drench enhanced vegetative growth (plant height, shoot length, root length, and number of branches) and reproductive parameters (flower number, fruit number, and fresh weight) of tomato. The enhancement of growth parameters by spraying of Vicia faba plants with commercial or algal extracts may be due to the presence of cytokinins, minerals and many of nutrient in commercial or algal extracts. These ingredients are known to improve the growth and increase cell division and cell enlargement (Ahmed et al., 2014). This might explain the remarkable increase in shoot height plants even than their control counter parts.

Our results in Table (5) showed that commercial algae and algal extracts caused remarkable improvement in yield parameters comparing to drought stress. These results in agreement to those obtained by (Jayaraj et al., 2008); (Khan et al., 2009) and (Hernández-Herrera et al., 2014), who revealed that, in recent years, the use of bio stimulants, often based on natural extract such as from seaweeds, has been proposed as a sustainable Strategy for improving crop yields without adversely impacting on the environment.

\section{Chemical constituents:}

Results recorded in Tables (6 and 7) revealed that, in most cases, Chl.a, Chl.b, Chl. $a+b$ and carotenoids contents of shoot of faba bean plants increased at stage I and decreased at stage II as a result of all treatments. Plants adapt to drought stress through synthesis of osmoprotectants (osmolytes or compatible solutes) which are lowmolecular-weight and highly soluble compounds that are usually nontoxic even at high cytosolic concentrations (Tekle and Alemu, 2016). Drought stress caused a significant increase in total soluble carbohydrates and protein contents of Vicia faba plants. These results are in harmony with those of (Mohamed and Akladious, 2014). This increases in soluble compounds can protect the cell under stress by balancing the osmotic strength of the cytosol with 
A. D. El-Gamal, et al.,

Table 1: Effects of drought stress and bio stimulant (Canada Power, Oligo $X$, and Corallina elongata, Sargassum latifolium extracts) on shoot length and root length of bean plants .

\begin{tabular}{|c|c|c|c|c|}
\hline \multirow{2}{*}{ Treatments } & \multicolumn{2}{|c|}{$\begin{array}{c}\text { Shoot length } \\
\text { means of 10 replicates }\end{array}$} & \multicolumn{2}{c|}{$\begin{array}{c}\text { Root length } \\
\text { means of 10 replicates }\end{array}$} \\
\cline { 2 - 5 } & Stage I & Stage II & Stage I & Stage II \\
\hline Control & $36.5 \pm 1.947$ & $41.056 \pm 1.886$ & $14.386 \pm 1.302$ & $14.86 \pm 1.287$ \\
\hline Drought Stress & $29.611 \pm 1.889$ & $32.111 \pm 2.254$ & $12.164 \pm 0.952$ & $12.097 \pm 1.074$ \\
\hline Stress + Carollina extract. & $30.744 \pm 1.59$ & $36.178 \pm 1.501$ & $7.744 \pm 0.763$ & $7.91 \pm 0.68$ \\
\hline Stress + Sargassum extract. & $32.367 \pm 0.589$ & $37.3 \pm 0.656$ & $14.221 \pm 1.008$ & $14.089 \pm 1.007$ \\
\hline Stress + Canada Power & $31.067 \pm 0.912$ & $34.467 \pm 0.856$ & $9.117 \pm 0.763$ & $8.472 \pm 0.735$ \\
\hline Stress + Oligo-X & $30.144 \pm 0.542$ & $33.9 \pm 0.656$ & $11.283 \pm 1.398$ & $11.912 \pm 1.557$ \\
\hline LSD 5\% & 2.036 & 4.012 & 3.021 & 2.321 \\
\hline
\end{tabular}

Table 2: Effects of drought stress and bio stimulant (Canada Power, Oligo $\mathrm{X}$, and Corallina elongata, Sargassum latifolium extracts) on fresh and dry weights of shoots of bean plants

\begin{tabular}{|l|c|c|c|c|}
\hline \multirow{2}{*}{\multicolumn{1}{|c|}{ Treatments }} & \multicolumn{2}{c|}{ F. Wt. shoot } & \multicolumn{2}{c|}{$\begin{array}{c}\text { D. Wt. shoot } \\
\text { means of ten replicates }\end{array}$} \\
\cline { 2 - 5 } & Stage I & Stage II & Stage I & Stage II \\
\hline Control & $31.172 \pm 5.76$ & $35.901 \pm 5.65$ & $2.87 \pm 0.0904$ & $3.855 \pm 0.0892$ \\
\hline Drought Stress & $22.099 \pm 3.65$ & $23.472 \pm 4.104$ & $2.502 \pm 0.254$ & $2.87 \pm 0.286$ \\
\hline Stress + Corallina extract & $26.479 \pm 1.74$ & $29.332 \pm 1.741$ & $2.706 \pm 0.156$ & $2.99 \pm 0.157$ \\
\hline Stress + Sargassum extract & $27.195 \pm 1.49$ & $30.034 \pm 1.496$ & $2.951 \pm 0.0114$ & $3.254 \pm 0.0114$ \\
\hline Stress + Canada Power & $25.965 \pm 1.05$ & $27.093 \pm 1.052$ & $2.854 \pm 0.0091$ & $3.054 \pm 0.00909$ \\
\hline Stress + Oligo-X & $24.523 \pm 1.11$ & $26.487 \pm 1.121$ & $2.644 \pm 0.0085$ & $2.944 \pm 0.00855$ \\
\hline \multicolumn{1}{|c|}{ LSD 5\% } & 4.321 & 4.165 & 0.221 & 0.435 \\
\hline
\end{tabular}

Table 3: Effects of drought stress and bio stimulant (Canada Power, Oligo $\mathrm{X}$, and Corallina elongata, Sargassum latifolium extracts) on Fresh and dry weights of roots of bean plants

\begin{tabular}{|l|c|c|c|c|}
\hline \multirow{2}{*}{\multicolumn{1}{|c|}{ Treatments }} & \multicolumn{2}{c|}{$\begin{array}{c}\text { F. Wt. of root } \\
\text { means of ten replicates }\end{array}$} & \multicolumn{2}{c|}{$\begin{array}{c}\text { D. Wt. of root } \\
\text { means of ten replicates }\end{array}$} \\
\cline { 2 - 5 } & Stage I & Stage II & Stage I & Stage II \\
\hline Control & $5.466 \pm 0.733$ & $5.376 \pm 0.723$ & $0.511 \pm 0.0366$ & $0.515 \pm 0.0365$ \\
\hline Drought Stress & $3.6 \pm 0.616$ & $3.553 \pm 0.693$ & $0.434 \pm 0.0496$ & $0.432 \pm 0.0557$ \\
\hline Stress + Corallina extract & $2.299 \pm 0.301$ & $2.36 \pm 0.304$ & $0.278 \pm 0.00298$ & $0.278 \pm 0.00299$ \\
\hline $\begin{array}{l}\text { Stress + Sargassum } \\
\text { extract }\end{array}$ & $4.207 \pm 0.625$ & $4.23 \pm 0.626$ & $0.327 \pm 0.0147$ & $0.327 \pm 0.0147$ \\
\hline Stress + Canada Power & $2.339 \pm 0.197$ & $2.217 \pm 0.192$ & $0.232 \pm 0.00498$ & $0.227 \pm 0.00401$ \\
\hline Stress + Oligo-X & $1.822 \pm 0.127$ & $1.806 \pm 0.127$ & $0.241 \pm 0.000273$ & $0.241 \pm 0.000273$ \\
\hline \multicolumn{1}{|c|}{ LSD 5\% } & 1.023 & 0.677 & 0.165 & 0.136 \\
\hline
\end{tabular}


Table 4: Effects of drought stress and bio stimulant (Canada Power, Oligo X,and Corallina elongata, Sargassum latifolium extracts) on leaves, flowers and branches numbers of bean plants

\begin{tabular}{|l|c|c|c|c|c|c|}
\hline \multirow{2}{*}{ Treatments } & \multicolumn{2}{|c|}{$\begin{array}{c}\text { No. leaves } \\
\text { means of ten replicates }\end{array}$} & $\begin{array}{c}\text { No. flowers } \\
\text { means of ten replicates }\end{array}$ & \multicolumn{2}{c|}{$\begin{array}{c}\text { No. branches } \\
\text { means of ten replicates }\end{array}$} \\
\cline { 2 - 7 } & Stage I & Stage II & Stage I & Stage II & Stage I & Stage II \\
\hline Control & $13.68 \pm 1.88$ & $15.37 \pm 1.89$ & $11.33 \pm 1.36$ & $13.585 \pm 1.37$ & $1.16 \pm 0.42$ & $1.30 \pm 0.39$ \\
\hline Drought Stress & $11.04 \pm 2.11$ & $\begin{array}{c}13.583 \pm \\
2.27\end{array}$ & $9.39 \pm 1.31$ & $10.054 \pm 1.34$ & $1.46 \pm 0.40$ & $1.648 \pm 0.36$ \\
\hline $\begin{array}{l}\text { Stress + Corallina } \\
\text { extract }\end{array}$ & $12.83 \pm 0.84$ & $14.60 \pm 0.85$ & $10.16 \pm 1.43$ & $12.275 \pm 1.43$ & $0.14 \pm 0.10$ & $0.136 \pm 0.10$ \\
\hline $\begin{array}{l}\text { Stress+Sargassum } \\
\text { extract }\end{array}$ & $12.97 \pm 0.77$ & $14.74 \pm 0.79$ & $10.56 \pm 0.99$ & $15.123 \pm 1.01$ & $0.37 \pm 0.16$ & $0.395 \pm 0.15$ \\
\hline $\begin{array}{l}\text { Stress + Canada } \\
\text { Power }\end{array}$ & $11.72 \pm 0.65$ & $14.04 \pm 0.67$ & $10.03 \pm 0.46$ & $14.841 \pm 0.45$ & $0.44 \pm 0.22$ & $0.525 \pm 0.21$ \\
\hline Stress+ Oligo-X & $12.30 \pm 0.59$ & $13.97 \pm 0.59$ & $9.65 \pm 0.68$ & $12.725 \pm 0.69$ & $0.43 \pm 0.22$ & $0.53 \pm 0.22$ \\
\hline \multicolumn{1}{|c|}{ LSD 5\% } & 0.537 & 0.633 & 0.645 & 0.74 & 0.325 & 0.215 \\
\hline
\end{tabular}

Table 5: Effects of drought stress and bio stimulant (Canada Power, Oligo $\mathrm{X}$, and Corallina elongata, Sargassum latifolium extracts) on yield Parameters of bean plants.

\begin{tabular}{|l|c|c|c|c|}
\hline \multirow{2}{*}{\multicolumn{1}{|c|}{ Treatments }} & \multicolumn{4}{|c|}{ Yield (means of ten replicates) } \\
\cline { 2 - 5 } & no. pods /plant & $\begin{array}{c}\text { WT pods (g) } \\
\text { /plant }\end{array}$ & $\begin{array}{c}\text { No. seed } / \\
\text { plant }\end{array}$ & $\begin{array}{c}\text { WT seed (g) } I \\
\text { plant }\end{array}$ \\
\hline Control & $9.556 \pm 0.53$ & $22.344 \pm 1.208$ & $27.556 \pm 1.215$ & $16.509 \pm 1.046$ \\
\hline Drought Stress & $6.00 \pm 0.745$ & $14.031 \pm 1.953$ & $19.222 \pm 2.067$ & $11.898 \pm 1.923$ \\
\hline $\begin{array}{l}\text { Stress + Corallina } \\
\text { extract }\end{array}$ & $7.032 \pm 0.309$ & $17.098 \pm 1.973$ & $22.889 \pm 1.968$ & $13.774 \pm 1.861$ \\
\hline $\begin{array}{l}\text { Stress + Sargassum } \\
\text { extract }\end{array}$ & $8.333 \pm 0.333$ & $18.278 \pm 1.399$ & $24.111 \pm 1.172$ & $14.427 \pm 1.241$ \\
\hline Stress + Canada Power & $7.222 \pm 0.364$ & $16.398 \pm 1.252$ & $23.667 \pm 1.00$ & $12.843 \pm 0.943$ \\
\hline Stress + Oligo-X & $7.078 \pm 0.222$ & $15.103 \pm 0.593$ & $21.556 \pm 0.58$ & $13.729 \pm 0.575$ \\
\hline \multicolumn{1}{|c|}{ LSD 5\% } & 2.014 & 3.215 & 4.012 & 1.854 \\
\hline
\end{tabular}

that of the vacuole and the external environment (Anjum et al., 2011). The importance of seaweed extract (SWE) in stress water effect can be correlated to improvement of glycine betaine content in treated plants. In several plant species, a positive correlation between leaf osmotic potential and glycine betaine, $\beta$ alanine betaine, and proline betaine has been observed (Rhodes and Hanson, 1993).

Data in the present study are similar to those of (Genard et al., 1991) reported that glycine betaine delays the loss of photosynthetic activity by inhibiting chlorophyll degradation during storage conditions in isolated chloroplasts the decrease in chlorophyll under drought stress is mainly due to the damage of chloroplasts by reactive oxygen species (Smirnoff, 1993). The seaweed extract applied as foliar spray enhanced the leaf chlorophyll level in plants (Blunden et al., 1996). The effect of water deficit was notably reduced by the foliar application of SWE. The benefit effect of algae extracts in protecting chlorophyll degradation may be attributed to betaine and betaine-like compounds present in 
seaweed (Khan et al., 2009). In plants, betaines serve as a compatible solute that alleviates osmotic stress induced by salinity and drought stress. Glycine betaine protects physiological processes such as photosynthesis and protein synthesis under drought conditions (Sulpice et al., 1998). On the other hand, it has been reported (Zhang and Ervin,
2008) that positive anti-stress effects of seaweed extracts may be related to cytokinin activity. Cytokinins mitigate stress-induced free radicals by direct scavenging and by preventing reactive oxygen species (ROS) formation by inhibiting xanthine oxidation (Fike et al. 2001).

Table 6: Effects of drought stress (in presence or absence of) and bio stimulant (Canada Power, Oligo $\mathrm{X}$, and Cor. elongata, Sargassum latifolium extracts) on Chlorophyll $a$ and $b$ of bean plants at I and II stages.

\begin{tabular}{|l|c|c|c|c|}
\hline \multirow{2}{*}{\multicolumn{1}{|c|}{ Treatments }} & \multicolumn{2}{c|}{ chlorophyll (a) } & \multicolumn{2}{c|}{ chlorophyll (b) } \\
\cline { 2 - 5 } & Stage I & Stage II & Stage I & Stage II \\
\hline Control & $2.805 \pm 1.281$ & $6.035 \pm 0.403$ & $1.512 \pm 0.991$ & $6.216 \pm 0.782$ \\
\hline Drought Stress & $2.571 \pm 1.46$ & $6.693 \pm 0.0844$ & $2.236 \pm 0.921$ & $7.627 \pm 1.143$ \\
\hline $\begin{array}{l}\text { Stress + Corallina } \\
\text { extract. }\end{array}$ & $3.091 \pm 0.946$ & $6.639 \pm 0.0761$ & $2.489 \pm 1.54$ & $6.232 \pm 0.177$ \\
\hline $\begin{array}{l}\text { Stress + Sargassum } \\
\text { extract. }\end{array}$ & $3.736 \pm 0.664$ & $6.512 \pm 0.0402$ & $2.621 \pm 1.133$ & $5.908 \pm 0.125$ \\
\hline Stress + Canada Power & $4.367 \pm 0.555$ & $6.459 \pm 0.318$ & $3.34 \pm 0.657$ & $5.198 \pm 1.725$ \\
\hline Stress + Oligo-X & $2.677 \pm 1.552$ & $6.813 \pm 0.211$ & $1.665 \pm 1.213$ & $7.545 \pm 0.846$ \\
\hline \multicolumn{1}{|c|}{ LSD 5\% } & 0.845 & 0.351 & 0.856 & 0.505 \\
\hline
\end{tabular}

Table 7: Effects of drought stress and bio stimulant (Canada Power, Oligo X, and Cor. elongata, Sargassum latifolium extracts) on total chlorophyll $(a+b)$ and Carotenoids of bean plants at I \& II stages

\begin{tabular}{|l|c|c|c|c|}
\hline \multirow{2}{*}{\multicolumn{1}{|c|}{ Treatments }} & \multicolumn{2}{c|}{ chlorophyll $(\mathrm{a}+\mathrm{b})$} & \multicolumn{2}{c|}{ Carotenoids } \\
\cline { 2 - 5 } & Stage I & Stage II & Stage I & Stage II \\
\hline Control & $4.317 \pm 2.272$ & $12.251 \pm 1.185$ & $1.214 \pm 0.477$ & $1.202 \pm 0.989$ \\
\hline Drought Stress & $4.806 \pm 2.381$ & $14.321 \pm 1.228$ & $1.087 \pm 0.702$ & $1.064 \pm 0.845$ \\
\hline Stress + Corallina extract & $5.581 \pm 2.486$ & $12.871 \pm 0.101$ & $1.251 \pm 0.239$ & $0.813 \pm 0.105$ \\
\hline $\begin{array}{l}\text { Stress + Sargassum } \\
\text { extract }\end{array}$ & $6.357 \pm 1.797$ & $12.42 \pm 0.165$ & $1.921 \pm 0.29$ & $0.996 \pm 0.145$ \\
\hline Stress + Canada Power & $7.707 \pm 1.213$ & $11.657 \pm 2.043$ & $1.998 \pm 0.155$ & $1.314 \pm 1.12$ \\
\hline Stress + Oligo-X & $4.341 \pm 2.765$ & $14.358 \pm 0.635$ & $1.205 \pm 0.626$ & $1.012 \pm 0.127$ \\
\hline \multicolumn{1}{|c|}{ LSD 5\% } & 1.251 & 0.684 & 0.154 & 0.135 \\
\hline
\end{tabular}

As recorded in Table (8) the increase in the protein content at lower concentration of seaweed fertilizer (SLF) might be due to absorption of most of the necessary elements by the seedlings (Kannan and Tamilselvan, 1994; Anantharaj and Venkatesalu, 2001, 2002).

Furthermore, the obtained results in Table (9) indicated that the soluble carbohydrates content increased up to $20 \%$ concentration of SLF and the content decreased at higher concentrations. The same trend was observed in the $\boldsymbol{H}$. musciformis with NPK application in blackgram (Tamilselvan and Kannan, 1994), V. catajung and $D$. bixorus (Anantharaj and Venkatesalu, 2001, 2002). 
Data illustrated in Table (10) showed no apparent trend with respect to amylase and protease activities. The most significant increases in amylase activities were observed in case of treated faba bean plants with stress + Corallina at stage 1 and stress + Oligo- $x$ at stage 2 . The highest increases of protease activities were observed in case of treated faba bean plants with stress + Canada power at both stages of growth.
The present results are in accordance with those obtained by (Sivasankari et al., 2006) observed that the $\alpha$-amylase activity was higher than the $\beta$ - amylase activity. Th $\alpha$ - amylase and $\beta$-amylase activity increased at lower concentrations of both the treatments of seaweeds.

Table 8: Effects of drought stress and bio stimulant (Canada Power, Oligo $X$, and Corallina elongata, Sargassum latifolium extracts) on soluble proteins of bean (plants) Shoot and Root at stages I and II; Values means of three replicates.

\begin{tabular}{|l|c|c|c|c|}
\hline \multirow{2}{*}{\multicolumn{1}{|c|}{ Treatments }} & \multicolumn{2}{c|}{ Protein Shoot } & \multicolumn{2}{c|}{ Protein Root } \\
\cline { 2 - 5 } & Stage I & Stage II & Stage I & Stage II \\
\hline Control & $45.68 \pm 0.64$ & $39.21 \pm 1.44$ & $25.68 \pm 1.2$ & $19.96 \pm 0.21$ \\
\hline Drought Stress & $53.6 \pm 1.12$ & $46.8 \pm 0.16$ & $29.6 \pm 0.24$ & $21.16 \pm 0.2$ \\
\hline Stress + Corallina extract. & $48.32 \pm 2.21$ & $34.12 \pm 0.32$ & $22.52 \pm 0.12$ & $17.76 \pm 0.12$ \\
\hline Stress + Sargassum extract. & $50.76 \pm 1.12$ & $43.12 \pm 1.08$ & $33.96 \pm 0.48$ & $14.92 \pm 0.04$ \\
\hline Stress + Canada Power & $47.88 \pm 0.40$ & $41.21 \pm 1.04$ & $28.52 \pm 0.12$ & $19.84 \pm 0.12$ \\
\hline Stress + Oligo-X & $43.72 \pm 2.08$ & $35.68 \pm 2.04$ & $23.4 \pm 0.48$ & $16.88 \pm 0.52$ \\
\hline \multicolumn{1}{|c|}{ LSD 5\% } & 7.21 & 5.35 & 3.65 & 1.44 \\
\hline
\end{tabular}

Table 9: Effects of drought stress and bio stimulant (Canada Power, Oligo X,and Corallina elongata, Sargassum latifolium extracts) on soluble carbohydrates of bean plants (shoot and root) at I and II stages;Values means of 3 replicates.

\begin{tabular}{|l|c|c|c|c|}
\hline \multirow{2}{*}{ Treatments } & \multicolumn{2}{|c|}{ Carbohydrate Shoot } & \multicolumn{2}{c|}{ Carbohydrates Root } \\
\cline { 2 - 5 } & Stage I & Stage II & Stage I & Stage II \\
\hline Control & $23.182 \pm 0.144$ & $21.983 \pm 0.12$ & $12.734 \pm 2.443$ & $9.536 \pm 0.431$ \\
\hline Drought Stress & $27.672 \pm 0.132$ & $29.988 \pm 1.67$ & $15.837 \pm 1.129$ & $13.636 \pm 0.718$ \\
\hline Stress + Corallina extract & $25.773 \pm 0.103$ & $22.983 \pm 1.12$ & $11.732 \pm 0.844$ & $9.744 \pm 0.12$ \\
$\begin{array}{l}\text { Stress + Sargassum } \\
\text { extract }\end{array}$ & $29.648 \pm 0.132$ & $25.98 \pm 0.65$ & $14.669 \pm 1.02$ & $12.684 \pm 0.65$ \\
Stress + Canada Power & $24.696 \pm 0.203$ & $19.636 \pm 0.84$ & $12.703 \pm 2.167$ & $8.146 \pm 0.467$ \\
\hline Stress + Oligo-X & $22.816 \pm 0.13$ & $22.696 \pm 0.25$ & $11.038 \pm 1.359$ & $11.708 \pm 0.239$ \\
\hline \multicolumn{1}{|c|}{ LSD 5\% } & 3.012 & 4.154 & 1.636 & 2.68 \\
\hline
\end{tabular}


A. D. El-Gamal, et al.,

Table 10: Effects of drought stress and bio stimulant (Canada Power, Oligo $\mathrm{X}$, and Corallina elongata, Sargassum latifolium extracts) on Amylase and Protease activities ( $\mathrm{mg} / \mathrm{g}$ dry weight) on bean plants at stages I and II; Values are means of three replicates.

\begin{tabular}{|l|c|c|c|c|}
\multirow{2}{*}{ Treatments } & \multicolumn{2}{c|}{ Amylase } & \multicolumn{2}{c|}{ Protease } \\
\cline { 2 - 5 } & Stage I & Stage II & Stage I & Stage II \\
\hline Control & $1.998 \pm 0.017$ & $2.045 \pm 0.106$ & $0.879 \pm 0.287$ & $0.00715 \pm 0.00715$ \\
\hline Drought Stress & $1.25 \pm 1.097$ & $1.718 \pm 0.442$ & $0.245 \pm 0.0055$ & $0.0203 \pm 0.00165$ \\
\hline Stress + Corallina extract. & $4.082 \pm 3.061$ & $1.509 \pm 0.463$ & $0.223 \pm 0.138$ & $0.0308 \pm 0.0077$ \\
$\begin{array}{l}\text { Stress + Sargassum } \\
\text { extract. }\end{array}$ & $1.386 \pm 0.74$ & $1.658 \pm 0.102$ & $0.16 \pm 0.0104$ & $0.124 \pm 0.0077$ \\
Stress + Canada Power & $1.25 \pm 0.706$ & $0.77 \pm 0.174$ & $0.525 \pm 0.263$ & $0.321 \pm 0.183$ \\
\hline Stress + Oligo-X & $1.224 \pm 1.224$ & $2.1 \pm 0.281$ & $0.236 \pm 0.088$ & $0.146 \pm 0.0407$ \\
\multicolumn{1}{|c|}{ LSD 5\% } & 0.718 & 0.141 & 0.142 & 0.158 \\
\hline
\end{tabular}

The demonstrated results in Table (11) showed that peroxidase activity of faba bean plants at both stages of growth increased in response to all treatments, with exceptions of stress + sargassum and stress + Canada power at stage1. In case of activities of superoxide dismutase and polyphenol oxidase showed decreases, mostly, in response to all treatments at both stages of growth as compared to stress conditions, with exception of increases in superoxide dismutase as a result of all treatments at stag 2 of faba bean plants. Our result may be explained by the effect of seaweed extract in reducing cell damage caused by reactive oxygen species (ROS) (Khan et al., 2009). Application of seaweed extract to turf grasses increased the activity of the antioxidant enzyme superoxide dismutase (SOD), which scavenges superoxide (Fike et al. 2001). Similarly, (Ayad, 1998) reported an increase in SOD of plants treated by seaweed extract. Many researchers have reported that seaweed extracts enhance the ascorbate peroxidase activities (Ayad, 1998), demonstrating the strong antioxidant properties of seaweeds which have been correlated to bioactive compounds (Meenakshi et al., 2009; O'Sullivan et al., 2011).
The obtained results in Tables (12\&13) indicated that total phenolic content was increased in faba bean plants because of different treatments (with exception of treatment with stress + Canada power) with respect to stress conditions. Acidic growth hormones, IAA, GA3 and ABA exhibited increases in GA3 contents of faba bean plants as a result to all treatments as comparison to stress condition, however IAA and ABA contents decreased, with exception of increasing $A B A$ contents as a result of treatment with stress + sargassum extract. Our results are similar to findings of (Nilsen and Orcutte, 1996) reported that, under drought, endogenous contents of auxins, gibberellins and cytokinin usually decrease, while those of abscisic acid and ethylene increase Nevertheless, phytohormones play vital roles in drought tolerance of plants. Auxins induce new root formation by breaking root apical dominance induced by cytokinins. As a prolific root system is vital for drought tolerance, auxins have an indirect but key role in this regard. Drought stress limits the production of endogenous auxins, usually when contents of abscisic acid and ethylene increase (Nilsen and Orcutte, 1996). 
Table 11: Effects of drought stress and bio stimulant (Canada Power, Oligo $\mathrm{X}$, and Corallina elongata, Sargassum latifolium extracts) on Peroxidase, Superoxidase dismutase and Polyphenol oxidase activities ( $\mu \mathrm{g} / \mathrm{g}$ dry weight) on bean plants at stage I and II; Values are means of three replicates.

\begin{tabular}{|l|c|c|c|c|c|c|}
\multirow{2}{*}{ Treatments } & \multicolumn{2}{|c|}{ Peroxidase } & \multicolumn{2}{c|}{$\begin{array}{c}\text { Superoxidase } \\
\text { dismutase }\end{array}$} & \multicolumn{2}{c|}{ Polyphenol oxidase } \\
\cline { 2 - 7 } & Stage I & Stage II & Stage I & Stage II & Stage I & Stage II \\
\hline Control & $82.5 \pm 52.5$ & $145.5 \pm 1.5$ & $408 \pm 42$ & $123 \pm 3$ & $6.6 \pm 0.6$ & $24 \pm 16.8$ \\
Drought Stress & $102 \pm 9$ & $94.5 \pm 13.5$ & $189 \pm 69$ & $192 \pm 84$ & $32.4 \pm 19.2$ & $25.2 \pm 8.4$ \\
Stress+Corallina extract & $168 \pm 111$ & $121.5 \pm 91.5$ & $144 \pm 96$ & $108 \pm 12$ & $6.6 \pm 0.6$ & $42.6 \pm 6$ \\
\hline $\begin{array}{l}\text { Stress + Sargassum } \\
\text { extract. }\end{array}$ & $64.5 \pm 22.5$ & $132 \pm 33$ & $111 \pm 57$ & $339 \pm 9$ & $17.4 \pm 0.6$ & $22.2 \pm 4.8$ \\
\hline Stress+ Canada Power & $96 \pm 48$ & $141 \pm 45$ & $267 \pm 39$ & $318 \pm 144$ & $5.4 \pm 0$ & $12.6 \pm 0$ \\
Stress + Oligo & $115.5 \pm 76.5$ & $127.5 \pm 61.5$ & $141 \pm 81$ & $525 \pm 63$ & $10.5 \pm 3.3$ & $19.8 \pm 13.8$ \\
\hline \multicolumn{1}{|c|}{ LSD 5\% } & 6.885 & 11.98 & 23.32 & 9.32 & 7.69 & 4.494 \\
\hline
\end{tabular}

Table 12: Effects of drought stress and bio stimulant (Canada Power, Oligo $\mathrm{X}$, and Corallina elongata, Sargassum latifolium extracts) on total phenol (mg of gallic acid / $100 \mathrm{~g}$ fr. wt.), seed yield protein and carbohydrates (mg/gm dry wt.) of bean plants. Values are means of three replicates.

\begin{tabular}{|l|c|c|c|}
\hline $\begin{array}{l}\text { Treatments } \\
\text { Control }\end{array}$ & $\begin{array}{c}\text { Phenol } \\
23.103 \pm 1.023\end{array}$ & $\begin{array}{c}\text { Protein } \\
213.16 \pm 3.12\end{array}$ & $\begin{array}{c}\text { Carbohydrates } \\
112.043 \pm 3.21\end{array}$ \\
\hline Drought Stress & $16.214 \pm 0.687$ & $225.76 \pm 1.54$ & $127.038 \pm 1.25$ \\
\hline Stress + Corallina extract. & $18.325 \pm 1.021$ & $197.56 \pm 2.08$ & $115.057 \pm 3.45$ \\
\hline Stress + Sargassum extract. & $21.216 \pm 0.478$ & $205.4 \pm 0.16$ & $129.024 \pm 0.98$ \\
Stress + Canada Power & $19.369 \pm 0.215$ & $188.12 \pm 2.04$ & $116.978 \pm 1.75$ \\
\hline Stress + Oligo-X & $17.236 \pm 0.987$ & $209.36 \pm 1.04$ & $122.055 \pm 2.65$ \\
\hline \multicolumn{1}{|c|}{ LSD 5\% } & 1.35 & 9.21 & 13.25 \\
\hline
\end{tabular}

Table 13: Effects of drought stress and bio stimulant (Canada Power, Oligo $\mathrm{X}$, and Cor. elongata, Sargassum latifolium extracts) on Phytohormones of bean plants Values are means of threereplicates.

\begin{tabular}{|l|c|c|c|}
\hline \multirow{2}{*}{ Treatments } & \multicolumn{2}{c|}{$\mathrm{mg} / 100 \mathrm{~g}$} & $\mu \mathrm{g} / 100 \mathrm{~g}$ \\
& $\mathrm{GA3}$ & $\mathrm{IAA}$ & $\mathrm{ABA}$ \\
\hline Control & $1.155 \pm 0.456$ & $1.182 \pm 0.214$ & $2.051 \pm 0.052$ \\
\hline Drought Stress & $1.165 \pm 0.214$ & $2.212 \pm 0.145$ & $0.655 \pm 0.154$ \\
\hline Stress + Corallina extract. & $3.021 \pm 0.123$ & $0.76 \pm 0.125$ & $0.454 \pm 0.215$ \\
Stress + Sargassum extract & $3.245 \pm 0.225$ & $0.536 \pm 0.069$ & $0.855 \pm 0.321$ \\
\hline Stress + Canada Power & $3.165 \pm 0.195$ & $0.863 \pm 0.087$ & $0.392 \pm 0.055$ \\
Stress + Oligo-X & $3.155 \pm 0.159$ & $0.486 \pm 0.051$ & $0.259 \pm 0.247$ \\
\hline
\end{tabular}

Polyphenols may act as antioxidants to protect the plant against oxidative stress (Grace, 2005). Increase in total phenolic content by application of SWE in bean plans can be explained by enzyme activation. It was reported (André et al., 2009) that treatment with SWE caused significantly enhanced activities of phenylalanine ammonia lyase (PAL) the most important enzyme responsible for biosynthesis of polyphenols. 


\section{Conclusion}

In the light of the present study, it seems reasonable to suggest that spraying of Vicia faba plants with commercial algae (Oligo $x$ and Canada power) and algal extract can successfully ameliorate the deleterious effects of drought stress as well as enhance the plant growth. Furthermore, it is worth noting that Sargassum extract were more effective than commercial algal in raising the plants' tolerance to drought. Therefore, we would venture to recommend the use of spraying Vicia faba plants with Sargassum extract as a new natural and low-cost method for not only the alleviation of drought stress on plants but also for stimulating growth with no discernible adverse effects.

\section{REFERENCES}

Afifi, W.M., M.I.Ahmed, Z.A.Moussa and M.F.Abd El-Hamid (1986). Effect of gamma irradiation and GA3 on amylase activity of pea seedlings. Ann. Agric. Sci., Moshtohor. 24(4):2047-2057.

Ahmed, F., D.M.Baloch, S.A.Sadiq, S.S.Ahmed, A.Hanan, S.A.Taran, N.Ahmed and M.J.Hassan (2014). Plant growth regulators induced drought tolerance in sunflower (Helianthus annuus L.) hybrids. The Journal of Animal and Plant Sciences, 24 (3), 886- 890.

Ajum, S.A., X.Y. Xie, L.C. Wang, M.F. Saleem, C. Man and W. Lei. (2011). Morphological, physiological and biochemical responses of plants to drought stress. African Journal of Agricultural Research. 6(9):2026- 32.

Ammar, M. H., A.M.Khan, H.M. Migdadi, S.M.Abdelkhalek and S.S. Alghamdi (2017).Faba bean drought responsive gene identification and validation', Saudi Journal of Biological Sciences. King Saud University, 24(1), pp. 80-89. doi: 10.1016/j.sjbs.2016.05.011.
Anantharaj, M. and V.Venkatesalu (2001). Effect of seaweed liquid fertilizer on Vigna catajung. Seaweed Res. Utiln. 23 (1\&2), 33-39.

Anantharaj, M. and V.Venkatesalu (2002). Studies on the effect of seaweed extracts on DolichosbiXorus. Seaweed Res. Utiln. 24 (1): 129-137.

André, C.M., R.Schafleitner, S.Legay, I.Lefèvre, C.A.Alvarado, A.G. Nomberto, L.Hoffmann, J.F. Hausman, Y.Larondelle and D.Evers (2009). Gene expression changes related to the production of phenolic compounds in potato tubers grown under drought stress. Phytochemistry 70:1107-1116.

Anjum, S.A., X.Xie, L.Wang, M.F.Saleem, C.Man and W.Lei (2011). Morphological, physiological and biochemical responses of plants to drought stress. African Journal of Agricultural Res., 6 (9), 2026-2032.

Ashraf, M. and P.J.C. Harris (2004). Potential biochemical indicators of salinity tolerance in plants. Plant Sci 166:13-16.

Atzmon, N. and J.Van Staden (1994). The effect of seaweed concentrates on the growth of Pinus pinea seedlings. New Forests 8: 3, 279-288.

Ayad, J.Y. (1998). The effect of seaweed extract (Ascophyllum nodosum) on antioxidant activities and drought tolerance of tall fescue (Festuca arundinacea Schreb.). Dissertation, Texas Tech University.

Bassal, S.A. and F.A. Zahran (2002). Effect of farmyard manure, bio and mineral nitrogen fertilizer and hill spaces on rice crop productivity. J. Agric. Sci. Mansoura Univ. 27: 19751988.

Blunden, G., T.Jenkins and Y.W.Liu (1996). Enhanced chlorophyll levels in plants treated with seaweed extract. J. Appl. Phycol. 8, 535-543. 
Crouch, I. J. and J.Van Staden (1991). Evidence for rooting factors in a seaweed concentrate prepared from Ecklonia maxima. J. Plant Physiol. 137: 319-322.

Crouch, I. J., M. T.Smith, J.Van Staden, M. J.Lewis and G. V.Hoad (1992). Identification of auxins in a commercial seaweed concentrate. J. Plant Physiol. 138: 590-594.

Daniel, H.D. and C.M.George (1972). Peach seed dormancy in relation to endogenous inhibitors and applied growth substances. J. Amer. Soc. Hort. Sci. 97:651-654.

Earl, H. and R.F.Davis (2003). Effect of drought stress on leaf and whole canopy radiation use efficiency and yield of maize. Agron. J. 95, 688-696.

El-Sheekh, M. M. and A.El-Saied (2000). Effect of crude seaweed extracts on seed germination, seedling growth and some metabolic processes of ViciafabaL. Cytobios, 101:23-35.

Fike, J.H., V.G.Allen, R.E.Schmidt, X. Zhang, J.P.Fontenot, C.P.Bagley, R.L. Ivy, R.R.Evans, R.W.Coelho and D.B. Wester (2001).Tasco Forage: I. Influence of a seaweed extract on antioxidant activity in tall fescue and ruminants. J. Anim. Sci. 79:1011-1021.

Genard, H., J.Le Saos, J.P.Billard, A.Tremolieres and J. Boucaud (1991). Effect of salinity on lipid composition, glycine betaine content and photosynthetic activity in chloroplasts of Suaeda maritima. Plant Physiol. Biochem. 29:421 427 .

Grace, S. (2005). Phenolics as antioxidants. In: Smirnoff $\mathrm{N}$ (ed) Antioxidants and Reactive Oxygen Species in Plants. Blackwell, Oxford, pp 141-168.

Hashem, H.A. (2006). Physiological and molecular actions of jasmonic acid on soybean plant. Ph.D Thesis, Fac. of Sci., Ain Shams Univ., Cairo, Egypt.
Hernández-Herrera, R. M., F.SantacruzRuvalcaba, M. A.Ruiz-López, J.Norrie and G. Hernández-Carmona (2014). Effect of liquid seaweed extracts on growth of tomato seedlings (Solanum lycopersicum L.). J. Appl. Phycol. 26, 619-628. doi: 10.1007/s10811-0130078-4.

IPCC., (2007). Climate change (2007): The physical science basis-Contribution of working group $I$ to the fourth assessment report of the Intergovernmental Panel on climate change. http:Il www. ipcc. ch/ publications_ and data/ar4l wg1/en/contents.html.

Jaworek, D., W. Gruber and H.U. Bergmeyer (1974). Adenosine-5'diphosphate and adenosine -5'monophosphate', in Methods of enzymatic analysis. Elsevier, pp. 2127-2131.

Jayaraj, J., A.Wan, M.Rahman and Z. K.Punja (2008). Seaweed extract reduces foliar fungal diseases on carrot. Crop Prot. 10, 1360-1366. doi: 10.1016/j.cropro. 2008.05.005

Kannan, L. and C.Tamilselvan (1990). Effect of seaweed manures on Vigna radiatus. Perspectives in phycology. (Prof. M.O.P. lyenger Centenary Celebration Volume) V.N. Rajarao (Ed.), pp. 427-430.

Khan, W., P. Usha and R.Sowmyalakshmi (2009). Seaweed extracts as biostimulants of plant growth and development. J Plant Growth Regul 28:386-399

Kinnaert, C. Mathilde Daugaard, Faranak Nami and Mads H. Clausen (2017). Chemical Synthesis of Oligosaccharides Related to the Cell Walls of Plants and Algae, Chemical Reviews.

doi: 10.1021/acs.chemrev.7b00162.

Kumari, R., I. Kaur and A. K. Bhatnagar (2011). Effect of aqueous extract of 
Sargassum johnstonii Setchel \& Gardner on growth, yield and quality of Lycopersicon esculentum Mill. J. Appl. Phycol. 23: 623 - 633.

Lichtenthaler,H.K. (1987). Photosynthesis IV. Philadelphia. Balaban Internat Science Service. p. 273-285.

Lowery, O.H., N.J.Rosebrough, A.I.Furr and R.J.Randall (1951). Protein measurement with folin phenol reagents. J. Biol. Chem, 193: 265-275.

Marklund, S. and G.Marklund (1974). Involvement of the Super Oxide Anion Radical in the Aut Oxidation of Pyro Gallol and a Convenient Assay for Super Oxide Dis Mutase Ec-1.15.1.1. European Journal of Biochemistry, 47(3), 469-474.

Martin, M., T.Barbeyron, R.Martin, D.Portetelle, G.Michel and $M$. Vandenbol (2015). The cultivable surface microbiota of the brown alga Ascophyllum nodosum is enriched in macroalgal-polysaccharide-degrading bacteria. Frontiers in Microbiology, 6(DEC), 1-14.

https://doi.org/10.3389/fmicb.2015.01487

Matta, A. and A. E.Dimond (1963). Symptoms of Fusarium wilt in relation to quantity of fungus and enzyme activity in tomato stems, Phytopathology. Amer Phytopath ological Soc. 3340 Pilot Knob Road, ST Paul, MN 55121, 53(5), p. 574.

Meenakshi, S., D.M.Gnanambigai, S.T.Mozhi, M.Arumugam and T.Balasubramanian (2009). Total flavanoid and in vitro antioxidant activity of two seaweeds of rameshwaram coast. Glob. J. Pharmacol. 3:59-62

Mikhail, M, A. Anna V. Skriptsova, Elena L. Chaikina and Aleksei G. Klykov (2013). 'Effect of Water Extracts of Seaweeds on the Growth of Seedling Roots of Buckwheat (Fagopyrum esculentum Moench)', ljrras, 16(2), pp. 282-287.

Mohamed, H.I. and S.A.Akladious (2014). Influence of garlic extract on enzymatic and nonenzymatic antioxidants in soybean plants (Glycine max) grown under drought stress. Life Science Journal, 11 (3s), 46-58.

Mwanamwenge, J., S. P.Loss, K. H. M.Siddique and P. S.Cocks (1998). Growth, seed yield and water use of faba bean (Vicia faba L.) in a short season Mediterranean-type environment. Aust. J. Exp. Agric., 38: 171-180.

Nilsen, E.T. and D.M.Orcutte (1996). Phytohormones and plant responses to stress, in: Nilsen E.T., Orcutte D.M. (Eds.), Physiology of Plant under Stress: Abiotic Factors, Wiley, New York, pp: 183-198.

Norrie, J. and D. A.Hiltz (1999).Seaweed extract research and applications in agriculture. Agro-Food-Industry HiTech., March I April: 15-18.

O'Sullivan, A.M., Y.C. O'Callaghan, M.N.O'Grady, B. Queguineur, D. Hanniffy, D.J.Troy, J.P.Kerry and N.H. O'Brien (2011). Vitro and cellular antioxidant of seaweed extracts prepared from five brown seaweeds harvested in spring from the west coast of Ireland. Food Chem. 126:1064-1070

Oliver, H.F., R.H. Orsi, M. Wiedmann and K.J. Boor (2010). Listeria monocytogenes has a small core regulon and a conserved role in virulence but makes differential contributions to stress tolerance across a diverse collection of strains. Appl. Envir. Microb.76:42 1632.

Ong, P.S. and G.M. Gaucher (1972). Protease production by thermophillic fungi. Can. J. Microbiology, 19:129133. 
Parker, Helen. L., Jennifer R. Dodson, Vitaly L. Budarin, James H. Clark and Andrew J. Hunt (2015). Direct synthesis of $\mathrm{Pd}$ nanoparticles on alginic acid and seaweed supports, Green Chemistry. Royal Society of Chemistry, 17(4), pp: 2200-2207. doi: 10.1039/c4gc02375g.

Rhodes, D. and A.D.Hanson (1993). Quaternary ammonium and tertiary sulfonium Compounds in higher plants. Annu. Rev. Plant Physiol. Plant Mol. Biol. 44:357-384.

Shindy, W.W. and O.Smith (1975). Identification of plant hormones from cotton ovules. Plant Physiol., 55: 550554.

Sivasankari, S., V.Venkatesalu, M. Anantharaj and M.Chandrasekaran (2006). Effect of seaweed extracts on the growth and biochemical constituents of Vigna sinensis. Bioresource Technology 97 (2006) 1745-1751.

Smirnoff, N. (1993). The role of active oxygen in the response of plants to water deficit and desiccation. New Phytol., 125: 27-58.

Snedecor, G.M. and W.G.Cochran (1982). Statistical methods 7th edition, lowa State Univ., Press, Ames, lowa U.S.A., pp: 325-330.

Strik, W. A., G. D.Arthur, A. F.Lourens, O.Novok, M.Strand and J.Van-Staden (2004). Changes in seaweed concentrates when stores at an elevated temperature. Journal of Applied Phycology 16: 31-39.

Sulpice, R., Y.Gibon, A. Bouchereau and F.Larher (1998). Exogenously supplied glycine betaine in spinach and rapeseed leaf discs: Compatibility or non-compatibility? Plant Cell Environ 21:1285-1292

Tamilselvan, C. and L.Kannan (1994). Studies on the utilization of seaweeds as fertilizer for black gram. Indian $\mathbf{J}$. Agric. Res. 28 (2): 121-126.

Tekle, A.T. and M.A.Alemu (2016). Drought tolerance mechanisms in field crops. World Journal of Biology and Medical Sciences, 3 (2): 15-39.

Thirumaran, G., M.Arumugam, R. Arumugam and $P$. Anantharaman (2009). Effect of Seaweed Liquid Fertilizer on Growth and Pigment Concentration of Abelmoschus esculentus (L.) Medikus. American Eurasian Journal of Agronomy 2 (2): 57-66.

Umbreit, W.W., R.H. Burris, J.F. stauffer, P.P. Cohen, W.J. Johnson, L. G.A. page and W.C. Schneider (1969). Manometric techniques, manual describing methods applicable to the studs of tissue metabolism. Burgess publishing Co., U.S.A., pp: 239.

Usman, M. (2014). Impact of heat and drought stress on physiological, biological processes in plants, technology times. Faisalabad, Pakistan: University of Agriculture. http://www.technologytimes.pk/

Van Staden, J., R. P.Beckett and M. J. Rijkenberg (1995). Effect of seaweed concentrate on the growth of the seedlings of three species of Eucalyptus. S. Afr. J. Bot. 61(4): 169172.

Vernon, L.P. and G.R.Selly (1966). The chlorophylls. Acad. Press, New York, London.

Wang, Q., W.Y.Shi, F. J.Rong, J. W.Ma, C. H.Guan and L. N.Jiang (2005). The effect of the liquid seaweed extract on resisting salinity stress of cucumber. Acta Agriculturae Zhejiangensis. 17: 268-272.

Zhang, X. and E. H. Ervin (2008). Impact of seaweed extract-based cytokinins and zeatin riboside on creeping bent grass heat tolerance. Crop Sci. 48: 364 -370 . 
دراسات مقارنة بين مستخلصات الطحالب البحرية والطحالب التجارية لتخفيف التأثير الضار

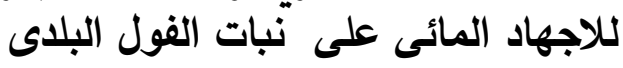

أحمد درويش الجمل، محمد عبدالحميد إسماعيل، محمد عبدالعال أمين،

عبد الرحمن محمود سيد

قسم النبات والميكروبيولوجي، كلية العلوم، جامعة الأزهر، القاهرة، مصر.

الملخص العربي

أجريت هذه التجربة فى الحديقة النباتية لكلية العلوم جامعة الأزهر بمدينة نصر القاهرة. تم دراسة تأثير نوعين من

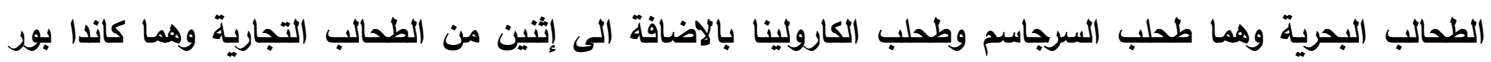

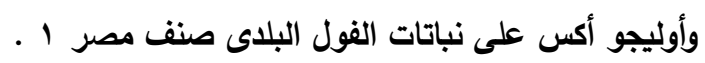

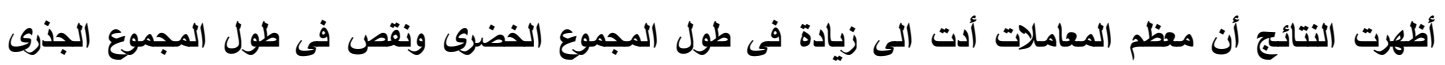

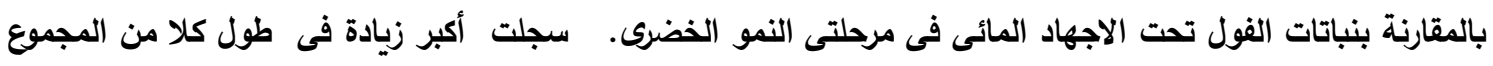

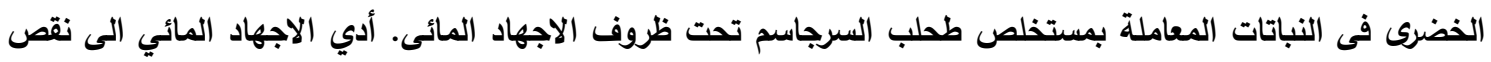

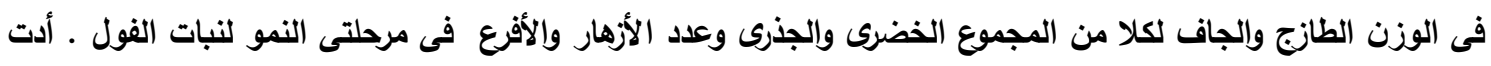

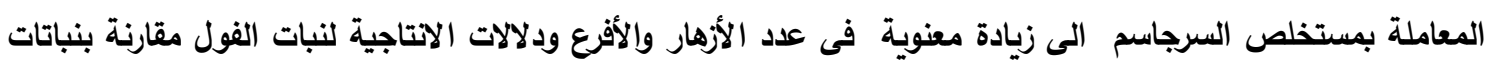

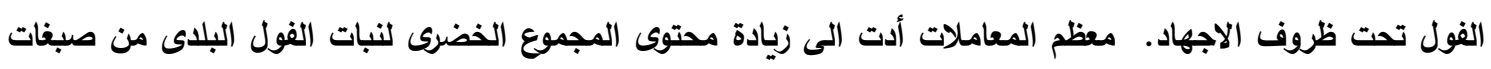

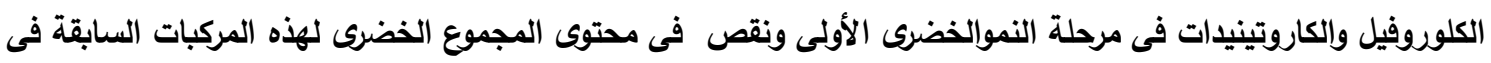

مرحلة النمو الثانية. أظهرت نباتات الفول تحت ظروف الاجهاد تحسنا معنويا في محتوي النبات (الجذور والمجموع الخضري والبذور) من

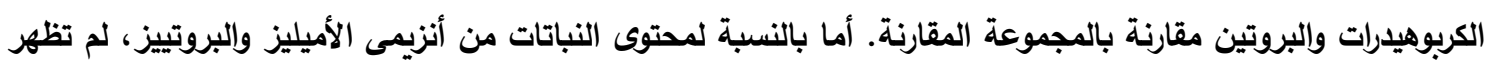

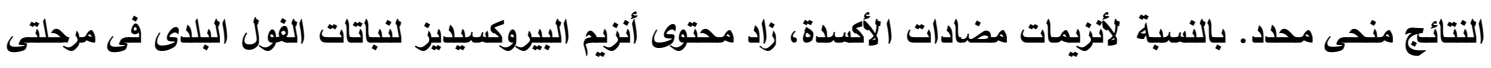

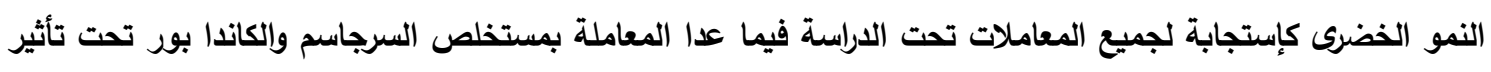

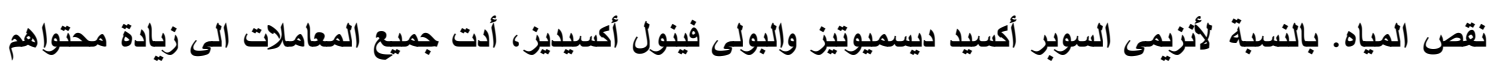

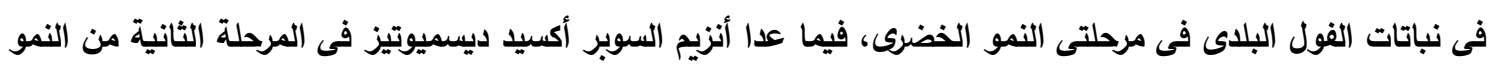

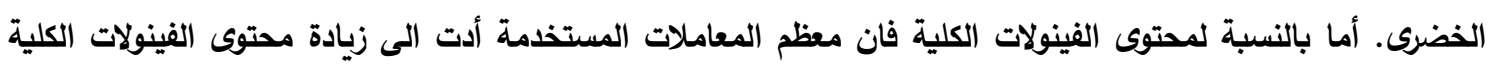

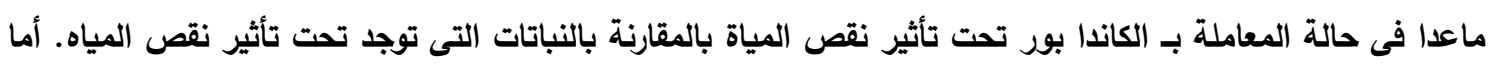

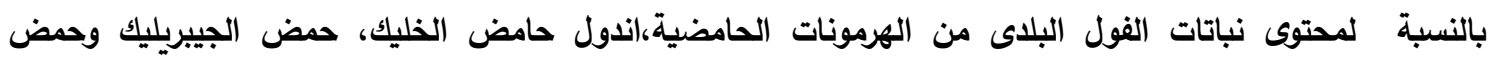

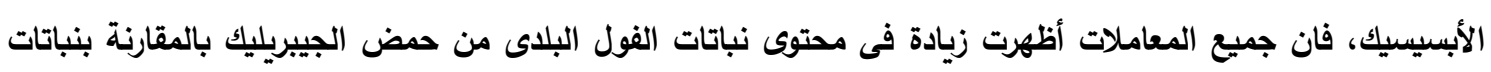

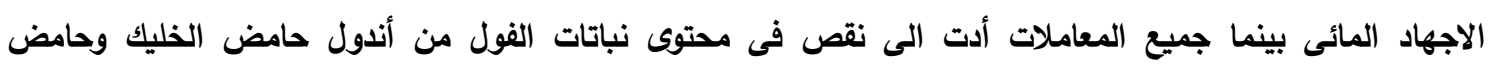

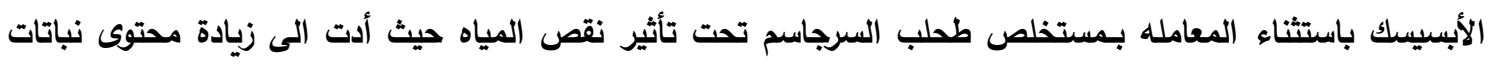

الفول البلدى من حامض الأبسيسيك.

السادة المحكمين

أ.د عماد الدين عباس كلية العلوم - جامعة الأزهر، أ.د مرفت إدوارد سوريا ل كلية الزراعة - جامعة المنوفية 